\section{Nitrogen Fertilization of Florida-grown Tomato Transplants: Seasonal Variation in Greenhouse and Field Performance}

\author{
C.S. Vavrina \\ University of Florida, Southwest Florida Research and Education Center, \\ 2686 State Road 29N, Immokalee, FL 34143
}

G.J. Hochmuth

University of Florida, Horticultural Sciences, P.O. Box 110690, Gainesville, FL 32611

J.A. Cornell

University of Florida, Department of Statistics, P.O. Box 110339, Gainesville, FL 32611

\section{S.M. Olson}

University of Florida, North Florida Research and Education Center, Rt. 3, Box 4370, Quincy, FL 32351

Additional index words. Lycopersicon esculentum, seedlings, containerized vegetable transplants, field establishment, plant size, yield, fruit size

Abstract. Fall-grown tomato (Lycopersicon esculentum Mill.) transplants were larger than spring-grown transplants when fertilized in the greenhouse with $\mathrm{NH}_{3} \mathrm{NO}_{3}$ at $0,15,30,45$, 60 , or $75 \mathrm{mg} \cdot \mathrm{L}^{-1} \mathrm{~N}$ in a standard $1 / 4$ strength Hoagland's solution. All transplant growth characteristics measured (stem length, leaf area and number, root and shoot dry mass) increased linearly with increasing $\mathrm{N}$ in both seasons. However, in the fall, when greenhouse temperatures and light levels were higher, stem length, leaf area, root : shoot ratio, and the ratio of shoot dry weight : leaf area responded quadratically. In the spring, total fruit yield and production of extra-large fruit increased with increasing transplant $\mathbf{N}$ fertilization, but the opposite trend occurred in the fall. These differing seasonal responses suggest fundamental differences in tomato transplant growth that must be addressed by modifications in $\mathbf{N}$ fertilization between spring and fall.

Tomato is the most important vegetable transplant grown in Florida (Vavrina and Summerhill, 1992) and has been the transplant crop most targeted for mineral nutrition research (Dufault, 1997). Work on transplant fertilization began almost as early as transplant utilization itself(Henderson, 1883; Tracy, 1908). With the advent of commercially available synthetic fertilizers, more scientificallybased and precise transplant nutrition studies were undertaken. To date, however, few specific recommendations concerning tomato transplant nutrition can be made, due to the varied scientific approaches ( $\mathrm{N}$ sources, number of applications, initiation of treatments, cultivars, etc.) undertaken.

Several studies (Table 1) have examined the effects of $\mathrm{N}$ application on growth of tomato transplants and on yield following planting in the field. While scientifically sound, these studies were quite varied in approach

\footnotetext{
Received for publication 10 Feb. 1997. Accepted for publication 11 July 1997. Florida Agricultural Experiment Station Journal Series no. R-05239. The use of brand names does not constitute a recommendation by the University of Florida to the exclusion of other products. The cost of publishing this paper was defrayed in part by the payment of page charges. Under postal regulations, this paper therefore must be hereby marked advertisement solely to indicate this fact.
}

(processing vs. fresh-market tomatoes, fertilitrue leaf, five vs. 42 applications), and several included the manipulation of additional factors such as light, temperature, or pre-transplant nutrient charges. Six of these eight studies were carried out above $42^{\circ} \mathrm{N}$ latitude and all studies were for spring plantings.

Despite considerable variability in approach, most studies have shown that $200-400$ $\mathrm{mg} \cdot \mathrm{L}^{-1} \mathrm{~N}$ maximized early yield (Masson et al., 1991b; Melton and Dufault, 1991b; Weston and Zandstra, 1989), but not always total yield (Masson et al., 1991b; Weston and Zandstra, 1989). One study showed that $75 \mathrm{mg} \cdot \mathrm{L}^{-1} \mathrm{~N}$ increased yield over higher rates (Garton and Widders, 1990) and another showed $350 \mathrm{mg} \cdot \mathrm{L}^{-1}$ N reduced field survival (Liptay and Nicholls, 1993).

In Florida, transplants are grown almost year-round to satisfy diverse field planting schedules (Vavrina and Summerhill, 1992). Florida transplant irrigation and fertigation frequencies are different from those of northern climates because of differences in atmospheric evaporative demand at different times of the year. Furthermore, the Florida tomato grower insists on a specific finished plant height $(10$ to $12 \mathrm{~cm})$, which often precludes the use of high $\mathrm{N}$ fertilization in the greenhouse. The objective of this study was to determine zation beginning at emergence vs. at second appropriate $\mathrm{N}$ fertilization for tomato transplant production under varying seasonal conditions and how transplant $\mathrm{N}$ nutrition would impact crop yield.

\section{Materials and Methods}

Twenty-four, 200 -cell $(2.5 \mathrm{~cm} \times 2.5 \mathrm{~cm} \times$ $6.7 \mathrm{~cm}$ ) styrofoam transplant flats (Speedling, Sun City, Fla.) were filled with MetroMix 220 (The Scotts Co., Marysville, Ohio), wetted to saturation, and seeded with 'All Star' (Petoseed, Saticoy, Calif.) tomato. The soilless media (70\% peat moss, $30 \%$ vermiculite) contained no initial nutrients other than that which could be mineralized from the native peat or desorbed from the vermiculite. Plants were grown under natural light conditions (14.5-19.0 MJ $\cdot \mathrm{m}^{-2} \cdot \mathrm{day}^{-1}$ fall, 9.5-11.0 $\mathrm{MJ} \cdot \mathrm{m}^{-2} \cdot$ day $^{-1}$ spring) and seasonal air temperatures $\left(23-32{ }^{\circ} \mathrm{C}\right.$ fall, $13-24{ }^{\circ} \mathrm{C}$ spring). Fall trials were generally seeded in early August and spring trials were seeded in midDecember.

Treatments consisted of five $\mathrm{N}$ rates: 15 , $30,45,60$, and $75 \mathrm{mg} \cdot \mathrm{L}^{-1} \mathrm{~N}$, derived from ammonium nitrate $\left(\mathrm{NH}_{4} \mathrm{NO}_{3}\right)$ and a control treatment without $\mathrm{N}$. Additional nutrients were supplied with a $25 \%$-strength Hoagland's (Hoagland and Arnon, 1950) solution including micronutrients and iron (Lorenz and Maynard, 1989). Each transplant tray was irrigated/fertigated daily with $10 \mathrm{~L}$ of the respective nutrient solutions until media saturation (10 min), except when evapotranspiration was low. Irrigation frequency was determined by assessing media saturation through hand estimation of tray mass. On average, fewer irrigations/fertigations were used in the spring (18) than in the fall (22) because of lower evaporative demand in the spring.

Treatments were applied with ebb and flow irrigation and were begun when the first true leaf was $\approx 1.25 \mathrm{~cm}$ in length ( 8 to $10 \mathrm{~d}$ after seeding). Our ebb and flow system was designed to float one flat in $10 \mathrm{~L}$ of solution. Fertilizers were included in the irrigation water. This regime was altered slightly in the fall when supplemental, light, overhead irrigations were used occasionally during the late afternoon on 4- to 5-week-old plants to prevent wilting. Six ebb and flow tanks (one for each $\mathrm{N}$ rate) were used to complete one replication at a time. The solution remaining after saturation of the replicate was poured out and was replaced with fresh solution before the next replicate was treated. The treatments were replicated four times within the greenhouse. The experiment was repeated over a 2-year period to include two spring and two fall seasons.

Five weeks after seeding, 10 plants were randomly selected and stem length, shoot dry mass, root dry mass, and leaf area (LI-3000A portable area meter; LI-COR, Lincoln, Nebr.) and number were recorded. Root : shoot, and shoot dry mass : leaf area ratios were calculated. One hundred shoot samples per treatment per replication were collected for analysis of final plant $\mathrm{N}$ concentration. Dried tissue was ground to pass through a $0.5-\mathrm{mm}$ mesh screen, and digested with sulfuric acid and 
Table 1. Reported responses to $\mathrm{N}$ in containerized tomato transplant nutrition studies.

\begin{tabular}{|c|c|c|c|}
\hline Reference & Cultivar & $\begin{array}{l}\mathrm{N} \text { rate }\left(\mathrm{mg} \cdot \mathrm{L}^{-1}\right) \text {, timing, and } \\
\text { number of applications }\end{array}$ & Field response \\
\hline $\begin{array}{l}\text { Weston and } \\
\text { Zandstra, } 1989\end{array}$ & Pic Red & $\begin{array}{l}100,200,400 \text { for } 5 \text { applications } \\
\text { beginning after first true leaf } \\
\text { emergence }\end{array}$ & $\begin{array}{l}200-400 \mathrm{mg} \cdot \mathrm{L}^{-1} \text { for maximum } \\
\text { early size and yield; total yield } \\
\text { and ave. fruit size not affected }\end{array}$ \\
\hline Widders, 1989 & Ohio 7870 & $\begin{array}{l}70 \text { twice weekly after emergence } \\
\text { for } 10 \text { applications, then starter } \\
\text { solutions of } 56,224 \text {, or } 392 \text { for } \\
8 \text { days prior to setting in field }\end{array}$ & $\begin{array}{l}224-392 \mathrm{mg} \cdot \mathrm{L}^{-1} \mathrm{~N} \text { gave } \\
\text { highest growth rate in field; } \\
\text { yield not reported }\end{array}$ \\
\hline $\begin{array}{l}\text { Garton and } \\
\text { Widders, } 1990\end{array}$ & Н 2653 & $\begin{array}{l}75 \text { or } 151 \text { daily from emergence to } \\
10 \text { days before transplanting then } \\
\text { imposed } N+P \text { pre-transplant } \\
\text { solutions }\end{array}$ & $\begin{array}{l}75 \mathrm{mg} \cdot \mathrm{L}^{-1} \text { daily produced } \\
\text { highest yields; } \mathrm{N}+\mathrm{P} \\
\text { pre-transplant solutions did not } \\
\text { affect yield }\end{array}$ \\
\hline $\begin{array}{l}\text { Melton and } \\
\text { Dufault, 1991a }\end{array}$ & Sunny & $\begin{array}{l}25,75,225 \text { beginning at second } \\
\text { true leaf stage for } 8 \text { applications }\end{array}$ & $\begin{array}{l}\text { Increasing } N \text { increased plant } \\
\text { field growth; yield not reported }\end{array}$ \\
\hline $\begin{array}{l}\text { Melton and } \\
\text { Dufault, 1991b }\end{array}$ & Sunny & $\begin{array}{l}100,200,300 \text { beginning at second } \\
\text { true leaf stage, } 3 \text { times/week } \\
\text { over } 9 \text { days. Another experiment } \\
\text { used } 50,100,200 \text { at first true leaf, } \\
3 \text { times/week over } 9 \text { days }\end{array}$ & $\begin{array}{l}200-300 \mathrm{mg} \cdot \mathrm{L}^{-1} \mathrm{~N} \text { increased } \\
\text { early and total yields }\end{array}$ \\
\hline $\begin{array}{l}\text { Masson et al., } \\
\text { 1991a }\end{array}$ & Springset & $\begin{array}{l}100,200,300,400 \text { twice daily } \\
\text { beginning } 1 \text { week after seeding } \\
\text { for } 23 \text { days }\end{array}$ & $\begin{array}{l}\text { Increasing } \mathrm{N} \text { increased } \\
\text { transplant size; yield not } \\
\text { reported }\end{array}$ \\
\hline $\begin{array}{l}\text { Masson et al., } \\
\text { 1991b }\end{array}$ & Springset & $\begin{array}{l}100,200,300,400 \text { twice daily } \\
\text { beginning } 1 \text { week after seeding } \\
\text { for } 23 \text { days }\end{array}$ & $\begin{array}{l}300-400 \mathrm{mg} \cdot \mathrm{L}^{-1} \mathrm{~N} \text { for high } \\
\text { early yield; NS for total yields }\end{array}$ \\
\hline $\begin{array}{l}\text { Liptay and } \\
\text { Nicholls, } 1993\end{array}$ & TH-318 & $\begin{array}{l}0,50,100,200,350 \text { at } 5 \\
\text { applications per week beginning } \\
10 \text { days after seeding for } \approx 29 \text { days }\end{array}$ & $\begin{array}{l}350 \mathrm{mg} \cdot \mathrm{L}^{-1} \mathrm{~N} \text { produced } \\
\text { highest early yield but lowest } \\
\text { survival; } 100+200 \mathrm{mg} \cdot \mathrm{L}^{-1} \mathrm{~N} \\
\text { had best field survival and early } \\
\text { fruit yield }\end{array}$ \\
\hline
\end{tabular}

hydrogen peroxide for $\mathrm{N}$ analysis by a rapidflow analyzer (Hanlon et al., 1994).

Three field plantings were made at separate locations in Immokalee, Fla., in Immokalee fine sand (sandy, siliceous, hypothermic, Arenic Haplaquods) in Spring 1993, Fall 1993, and Fall 1994. A fourth planting was in Orangeburg loamy fine sand (fine loamy, siliceous, thermic Typic Kandiudult) at the North Florida Research andEducation Center (Quincy, Fla.) in Spring 1995. The Immokalee field sites were subsurface irrigated and the Quincy field site was drip-irrigated. Cultural practices varied with field sites, but were within recommendations outlined by Hochmuth (1988).

Five-week-old seedlings were transplanted in a randomized complete-block design in replicated field trials (six replicates of each of six treatments) on 16 Feb. and 14 Sept. 1993, and 21 Sept. 1994 (Immokalee, Fla.) and on 21 Mar. 1995 (Quincy, Fla.). Individual plots consisted of 14 plants with a $46-\mathrm{cm}$ in-row and $1.8-\mathrm{m}$ between-row spacing. Mature green fruits were initially harvested 10 to 12 weeks later, depending on season. Harvests (three) were made at 7- to 10-d intervals and fruits from each harvest were sized according to specifications for ethylene-gassed green tomatoes (Hochmuth, 1988) into medium $(<6.4$ $\mathrm{cm}$ diameter), large $(6.5$ to $7.0 \mathrm{~cm})$, and extralarge $(>7.0 \mathrm{~cm})$ categories. Cull fruit $(<1 \%)$ were removed before sizing.

Transplant growth and fruit yield data were analyzed using a mixed-model analysis of variance (SAS, 1989) to test for differences between seasons, nitrogen treatments, and a season-by- $\mathrm{N}$ treatment interaction. To measure the effect of $\mathrm{N}$, regression analyses were performed over the levels of $\mathrm{N}$ from 15 to 75 $\mathrm{mg} \cdot \mathrm{L}^{-1} \mathrm{~N}$ only, after the data were $\log$ transformed. The reason for this was to use only treatments containing $\mathrm{N}$ to measure the effect of increasing $\mathrm{N}$. The data for $0 \mathrm{~N}$ were averaged and compared, using the LSD procedure, against the average response at $15 \mathrm{mg} \cdot \mathrm{L}^{-1} \mathrm{~N}$, to see if the averages differed.

The variation among the spring measurements was greater than that among the fall measurements for most of the data, forcing the use of logarithmic transformation to stabilize the seasonal variation. Furthermore, with nearly every response, the season $\times$ N interaction was highly significant $(P<0.01)$; therefore, the regression analysis for the effects of $\mathrm{N}$ was performed separately for each season.

Listed in Table 4 are the coefficient estimates $\left(b_{1}\right.$ and/or $\left.b_{2}\right)$ in the fitted regression equations having values significantly $(P<$ 0.05 ) different from zero. Associated with each fitted regression equation is an approximate value of the coefficient of determination $\left(R_{\text {Ave }}^{2}\right)$. The value of $R_{\text {Ave }}^{2}$ is only approximate since the data fitted were averaged across the four (plant samples) or six (yield) replicates rather than the individual values. Realizing that the approximate values of $\mathrm{R}_{\text {Ave }}^{2}$ are inflated slightly because the models were fitted to averages and not individual observations (Cornell and Berger, 1987), we have elected to present the $\mathrm{R}^{2}{ }_{\text {Ave }}$ values strictly for comparing the fits of the listed equations. The higher the $\mathrm{R}_{\text {Ave }}^{2}$ value, the better the model fits the data.

\section{Results and Discussion}

When 15 or more $\mathrm{mg} \cdot \mathrm{L}^{-1} \mathrm{~N}$ was applied, all seedling growth characteristics were greater in fall-grown than in spring-grown transplants
(Table 2). This was probably the result of higher fall light levels and temperatures. Increases in $\mathrm{N}$ fertilization increased transplant growth in both spring and fall seasons, which agrees with previous work by Widders (1989), Masson et al. (1991a), and Melton and Dufault (1991a). While most transplant growth characteristics increased linearly with increasing $\mathrm{N}$, a quadratic growth response was noted in stem length and leaf area of the fall-grown transplants (Tables 2 and 4). This difference in response of spring vs. fall transplants may indicate the need for modifications in fertilization depending on season.

Similarly, the fall root : shoot ratio decreased quadratically with increasing $\mathrm{N}$ while the spring ratio decreased linearly (Table 2 ). The shoot dry mass : leaf area ratio, an estimate of carbohydrate levels in the leaves (Yelle et al., 1989), decreased as $\mathrm{N}$ increased (Table 2). Marschner (1986) noted a reduction in photosynthate with increasing N. However, in the fall, the response to $\mathrm{N}$ was quadratic, further supporting seasonal growth pattern differences.

Whole-shoot tissue $\mathrm{N}$ concentration (Table 2) in both the spring and fall seasons appeared low by most tissue analysis standards (Hochmuth et al., 1991), regardless of $\mathrm{N}$ level in the nutrient solution. However, $\mathrm{N}$ sufficiency levels for tomato transplants are not well substantiated. These data are similar to the early field establishment $\mathrm{N}$ concentrations (9.3-13.5 $\mathrm{mg} \cdot \mathrm{g}^{-1}$ ) noted by Widders (1989), who used a transplant $\mathrm{N}$ level comparable to our highest rate and slightly less than the levels (17-26 $\mathrm{mg} \cdot \mathrm{g}^{-1}$ ) noted by Liptay and Nicholls (1993) at the lower end of their tomato transplant nutrition treatments. Tissue- $\mathrm{N}$ concentration in spring-grown plants increased with increasing transplant $\mathrm{N}$ applied. However, no discernible pattern was detected in tissue $\mathrm{N}$ of fall-grown transplants, except that the plants that received 60 and $75 \mathrm{mg} \cdot \mathrm{L}^{-1} \mathrm{~N}$ had significantly $(P<$ $0.05)$ greater $N$ concentrations than plants receiving lower $\mathrm{N}$ rates.

Seasonal fruit yield effects were confounded with location effects. However, a subsequent analysis of the spring data showed no difference between Immokalee and Quincy. First-harvest yield from spring-grown transplants increased with increasing $\mathrm{N}$ fertilization (Table 3). This trend substantiated findings from previous studies (Garton and Widders, 1990; Liptay and Nicholls, 1993; Masson et al., 1991b; Melton and Dufault, 1991b; Weston and Zandstra, 1989). Early extra-large fruit production also increased with increasing $\mathrm{N}$ fertilization in the spring. Total spring yield (three harvests) followed this trend, but no effect of transplant $\mathrm{N}$ was evident in overall spring extra-large fruit production. In all harvests, yield from the fall-grown transplants declined with increasing transplant $\mathrm{N}$ fertilization, whereas that of spring-grown transplants increased.

We found no correlation (data not shown) between transplant mortality after planting in the field and high $\mathrm{N}$ fertilization, as reported by Liptay and Nicholls (1993), but our rates were low compared to those of Liptay and 
Table 2. Effects of nitrogen application on tomato transplant characteristics for Fall (F) and Spring (S) seasons.

\begin{tabular}{|c|c|c|c|c|c|c|c|c|c|c|c|c|c|c|c|c|}
\hline \multirow{3}{*}{$\begin{array}{l}\text { Nitrogen } \\
\left(\mathrm{mg} \cdot \mathrm{L}^{-1}\right)\end{array}$} & \multirow{2}{*}{\multicolumn{2}{|c|}{$\begin{array}{l}\text { Tissue N } \\
\left(\mathrm{mg} \cdot \mathrm{g}^{-1}\right)\end{array}$}} & \multirow{2}{*}{\multicolumn{2}{|c|}{$\begin{array}{l}\text { Stem length } \\
(\mathrm{cm})\end{array}$}} & \multirow{2}{*}{\multicolumn{2}{|c|}{ No. leaves }} & \multirow{2}{*}{\multicolumn{2}{|c|}{$\begin{array}{c}\text { Leaf area } \\
\left(\mathrm{cm}^{2}\right)\end{array}$}} & \multicolumn{4}{|c|}{ Dry mass (g) } & \multirow{2}{*}{\multicolumn{2}{|c|}{$\begin{array}{c}\text { Root : shoot } \\
\text { ratio } \\
\end{array}$}} & \multirow{2}{*}{\multicolumn{2}{|c|}{$\begin{array}{c}\text { Shoot dry mass/ } \\
\mathrm{cm}^{2} \text { leaf area } \\
\end{array}$}} \\
\hline & & & & & & & & & \multicolumn{2}{|c|}{ Shoot } & \multicolumn{2}{|c|}{ Root } & & & & \\
\hline & F & $S$ & $\mathrm{~F}$ & $S$ & $\mathrm{~F}$ & $S$ & $\mathbf{F}$ & $\mathrm{S}$ & $\mathrm{F}$ & $\mathrm{S}$ & $\mathbf{F}$ & $\mathrm{S}$ & $\mathrm{F}$ & $\mathrm{S}$ & $\mathrm{F}$ & $\mathrm{S}$ \\
\hline $0^{2}$ & $14.3^{\mathrm{Ns}}$ & $9.0^{\mathrm{Ns}}$ & $3.8^{*}$ & $4.1^{*}$ & $2.0^{\mathrm{Ns}}$ & $2.0^{\mathrm{Ns}}$ & $2.8^{*}$ & $3.9^{*}$ & $0.03^{*}$ & $0.03^{\mathrm{Ns}}$ & $0.01^{\mathrm{Ns}}$ & $0.02^{\mathrm{NS}}$ & $0.46^{*}$ & $0.49^{*}$ & $0.0091^{\mathrm{Ns}}$ & $0.0078^{\mathrm{Ns}}$ \\
\hline 15 & 14.0 & 10.0 & 6.7 & 5.8 & 3.2 & 2.0 & 9.5 & 9.2 & 0.10 & 0.08 & 0.03 & 0.03 & 0.35 & 0.36 & 0.0100 & 0.0082 \\
\hline 30 & 14.1 & 11.0 & 10.2 & 7.9 & 3.9 & 2.5 & 18.1 & 14.9 & 0.17 & 0.11 & 0.05 & 0.04 & 0.30 & 0.33 & 0.0091 & 0.0075 \\
\hline 45 & 14.9 & 12.0 & 15.3 & 11.7 & 4.1 & 3.0 & 28.4 & 23.8 & 0.22 & 0.16 & 0.06 & 0.05 & 0.28 & 0.30 & 0.0077 & 0.0067 \\
\hline 60 & 17.1 & 14.0 & 21.6 & 14.4 & 4.5 & 3.2 & 38.2 & 31.3 & 0.27 & 0.20 & 0.07 & 0.06 & 0.24 & 0.29 & 0.0071 & 0.0063 \\
\hline 75 & 17.9 & 14.5 & 21.6 & 16.4 & 4.6 & 3.7 & 49.1 & 39.7 & 0.32 & 0.25 & 0.08 & 0.07 & 0.24 & 0.28 & 0.0066 & 0.0062 \\
\hline Significance & NS & $\mathrm{L}^{* *}$ & $\mathrm{~L}^{* *}, \mathrm{Q}^{* *}$ & $\mathrm{~L}^{* *}$ & $\mathrm{~L}^{* *}$ & $\mathrm{~L}^{* *}$ & $\mathrm{~L}^{* *}, \mathrm{Q}^{* *}$ & $\mathbf{L}^{* *}$ & $\mathrm{~L}^{* *}$ & $\mathrm{~L}^{* *}$ & $\mathrm{~L}^{* *}$ & $\mathrm{~L}^{* *}$ & $\mathrm{~L}^{* *}, \mathrm{Q}^{* *}$ & $\mathrm{~L}^{* *}$ & $\mathrm{~L}^{*}, \mathrm{Q}^{*}$ & $\mathrm{~L}^{*}$ \\
\hline
\end{tabular}

${ }^{2}$ Data for $0 \mathrm{~N}$ are either nonsignificant (NS) or significantly different (*) from $15 \mathrm{mg} \cdot \mathrm{L}^{-1}$ at $P \leq 0.05$ by LSD.

Ns, **** Nonsignificant, linear $(\mathrm{L})$, or quadratic $(\mathrm{Q})$ response at $P \leq 0.05(*)$ or $P \leq 0.01(* *)$ based upon log transformation.

Table 3. Effects of $\mathrm{N}$ application on yield from tomato transplants produced in Fall (F) and Spring (S) seasons.

\begin{tabular}{|c|c|c|c|c|c|c|c|c|}
\hline \multirow{3}{*}{$\begin{array}{l}\text { Nitrogen } \\
\left(\mathrm{mg} \cdot \mathrm{L}^{-1}\right)\end{array}$} & \multicolumn{4}{|c|}{ Extra-large $\left(\mathrm{MT} \cdot \mathrm{ha}^{-1}\right)$} & \multicolumn{4}{|c|}{ Total marketable $\left(\mathrm{MT} \cdot \mathrm{ha}^{-1}\right)$} \\
\hline & \multicolumn{2}{|c|}{ 1st harvest } & \multicolumn{2}{|c|}{ Total harvest } & \multicolumn{2}{|c|}{ 1st harvest } & \multicolumn{2}{|c|}{ Total harvest } \\
\hline & $\mathrm{F}$ & $\mathrm{S}$ & $\mathrm{F}$ & $\mathrm{S}$ & $\mathrm{F}$ & $\mathrm{S}$ & $\mathrm{F}$ & $\mathrm{S}$ \\
\hline $0^{z}$ & $2.3^{*}$ & $1.0^{*}$ & $19.4^{*}$ & $13.3^{*}$ & $3.4^{*}$ & $1.9^{*}$ & $37.2^{*}$ & $26.8^{*}$ \\
\hline 15 & 7.7 & 3.9 & 26.3 & 21.8 & 9.1 & 6.2 & 46.1 & 38.7 \\
\hline 30 & 7.8 & 5.5 & 25.6 & 27.4 & 9.3 & 9.0 & 45.4 & 50.5 \\
\hline 45 & 7.6 & 6.3 & 24.9 & 26.1 & 8.9 & 9.7 & 43.9 & 51.4 \\
\hline 60 & 6.2 & 7.2 & 19.7 & 26.1 & 7.7 & 10.9 & 41.1 & 53.8 \\
\hline 75 & 5.8 & 7.5 & 20.1 & 25.9 & 7.0 & 12.0 & 39.3 & 53.4 \\
\hline Significance & $\mathrm{L}^{* *}$ & $\mathrm{~L}^{* *}, \mathrm{Q}^{* *}$ & $\mathrm{~L}^{* *}$ & NS & $\mathbf{L}^{* *}$ & $\mathrm{~L}^{* *}, \mathrm{Q}^{* *}$ & $\mathbf{L}^{* *}$ & $\mathbf{L}^{* *}, \mathrm{Q}^{* *}$ \\
\hline
\end{tabular}

${ }^{2}$ Data for $0 \mathrm{~N}$ are significantly different (*) from those for $15 \mathrm{mg} \cdot \mathrm{L}^{-1}$ at $P \leq 0.05$ by LSD.

Ns, ${ }^{*},{ }^{* *}$ Nonsignificant, linear $(\mathrm{L})$, or quadratic $(\mathrm{Q})$ response at $P \leq 0.01\left(^{* *}\right)$ based upon $\log$ transformation.

Table 4. Coefficient estimates and approximate $R^{2}$ values of regression equations fitted to data in Table 2 and Table 3 at the levels of 15 to $75 \mathrm{ppm} \mathrm{N}$ only.

\begin{tabular}{|c|c|c|c|c|c|c|c|c|}
\hline \multirow[b]{2}{*}{ Response } & \multicolumn{3}{|c|}{ Fall } & \multirow[b]{2}{*}{$\mathrm{R}_{\text {Ave. }}^{2}$} & \multicolumn{3}{|c|}{ Spring } & \multirow[b]{2}{*}{$\mathbf{R}_{\text {Ave. }}^{2}$} \\
\hline & $\mathrm{b}_{0}$ & $\mathrm{~b}_{1}$ & $b_{2}$ & & $\mathrm{~b}_{0}$ & $\mathrm{~b}_{1}$ & $\mathrm{~b}_{2}$ & \\
\hline Tissue $\mathrm{N}$ & NS & & & & 0.87 & 0.008 & & 0.973 \\
\hline Stem length & 1.28 & 0.043 & $-2.6 \times 10^{-4}$ & 0.952 & 1.52 & 0.018 & & 0.730 \\
\hline Leaf area & 1.52 & 0.053 & $-2.9 \times 10^{-4}$ & 0.960 & 1.90 & 0.025 & & 0.889 \\
\hline No. leaves & 3.0 & 0.023 & & 0.687 & 1.65 & 0.027 & & 0.980 \\
\hline Shoot dry mass & -2.53 & 0.020 & & 0.866 & -2.85 & 0.020 & & 0.790 \\
\hline Root dry mass & -3.54 & 0.014 & & 0.905 & -3.82 & 0.015 & & 0.729 \\
\hline Root : shoot ratio & -0.87 & -0.014 & $8.5 \times 10^{-5}$ & 0.959 & -0.98 & -0.005 & & 0.904 \\
\hline \multicolumn{9}{|l|}{ Yield } \\
\hline \multicolumn{9}{|l|}{ Extra-large } \\
\hline 1st harvest & 2.26 & -0.005 & & 0.797 & 1.22 & 0.025 & $-1.8 \times 10^{-4}$ & 0.943 \\
\hline Total & 2.42 & -0.005 & & 0.839 & 1.58 & 0.026 & $-1.8 \times 10^{-4}$ & 0.939 \\
\hline \multicolumn{9}{|l|}{ Marketable } \\
\hline 1st harvest & 3.34 & -0.005 & & 0.782 & NS & & & \\
\hline Total & 3.86 & -0.003 & & 0.931 & 3.41 & 0.019 & $1.7 \times 10^{-4}$ & 0.892 \\
\hline
\end{tabular}

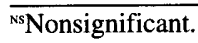

Nicholls (1993). Perhaps our more nutritionally hardened plants (i.e, lower $\mathrm{N}$ ) established more efficiently and hence did not exhibit excessive mortality. Further research documenting growth of plants once set in the field would be of value to help substantiate this hypothesis.

While only fall-grown transplants exhibited a quadratic growth response to $\mathrm{N}$ fertilization (Tables 2 and 4), only spring-grown transplants exhibited a quadratic yield response to increasing transplant $\mathrm{N}$ (Tables 3 and 4). This suggests that increasing transplant $\mathrm{N}$ is more limiting to yield in fall-grown than in springgrown transplants.

As transplant $\mathrm{N}$ fertilization increased, the physiological age of the plants increased as evidenced by leaf number (Table 2). This also was noted by Melton and Dufault (1991a) and supported by Marschner (1986). This result somewhat confounds the relationship between $\mathrm{N}$ fertilization and yield because the physiologically older plant generally produces ear- house environmental conditions). When growing transplants for fall crop production, lower $\mathrm{N}$ fertilizer rates $\left(20-30 \mathrm{mg} \cdot \mathrm{L}^{-1} \mathrm{~N}\right)$ should be used. Spring transplant fertilization (45 to 60 $\mathrm{mg} \cdot \mathrm{L}^{-1} \mathrm{~N}$ ) in Florida may impact yield of tomato plants shipped north for spring production. Although this impact cannot be accurately determined from our data, Florida air temperatures and light conditions in May, when many millions of plants are shipped north, are more like those of fall than those of spring. Still, more research is needed in this area before precise recommendations can be made.

\section{Literature Cited}

Cornell, J.A. and R.D. Berger. 1987. Factors that influence the value of the coefficient of determination in simple linear and nonlinear regression models. Phytopathology 77:63-70.

Dufault, R.M. 1997. Transplant production and performance: Effect of transplant nutrition. Proc. Natl. Symp. on Stand Establishment. Columbus, Ohio, June 1997. OARDC Hort. and Crop Sci. Ser. 668:40-62.

Garton, R. W. and I. E. Widders. 1990. Nitrogen and phosphorus preconditioning of small-plug seedlings influence processing tomato productivity. HortScience 25:655-657.

Hanlon, E.A., J.G. Gonzales, and J.M. Bartos. 1994. Institute of Food and Agricultural Sciences extension soil testing laboratory chemical procedures and training manual. Florida Coop. Ext. Serv. Circ. 812.

Henderson, P. 1883. Gardening for profit. Orange Judd Co., New York.

lier fruit. If harvested simultaneously with the other treatments, the plants treated with higher rates of $\mathrm{N}$ should therefore yield more extralarge fruit. This was true for the spring-grown transplants, as both total yield in the first harvest and the yield of extra-large fruit was highest with the highest $N$ rate used in the plant house. However, the opposite effects were obtained with fall-grown transplants. Liptay and Nicholls (1993) provide supporting evidence of high-N suppression of early yield, indicating that the highest early yield resulted from transplants receiving moderate $\left(100 \mathrm{mg} \cdot \mathrm{L}^{-1} \mathrm{~N}\right)$ levels of transplant $\mathrm{N}$ in spring trials.

We applied lower rates of $\mathrm{N}$ than those used in most studies because Florida tomato growers insist on a specific finished plant height (10 to $12 \mathrm{~cm})$, and $\mathrm{N}$ in excess of 100 $\mathrm{mg} \cdot \mathrm{L}^{-1} \mathrm{~N}$ under semi-tropical conditions leads to difficulties in transplant height management.

The results reported here indicate that transplant fertilization in Florida should be based on production season (i.e., extremes in green-
Hoagland, D.R and D.I. Arnon. 1950. The water culture method for growing plants without soil. California Agr. Expt. Sta. Circ. 347.

Hochmuth, G.J. (ed.). 1988. Tomato production guide for Florida. Florida Coop. Ext. Serv. Circ. 98C.

Hochmuth, G.J., D. Maynard, C.S. Vavrina, and E.A Hanlon. 1991. Plant tissue analysis and interpretation for vegetable crops in Florida. Florida Coop. Ext. Serv. Circ. SS-VEC-42.

Liptay, A. and S. Nicholls. 1993. Nitrogen supply during greenhouse transplant production affects subsequent tomato root growth in the field. J. Amer. Soc. Hort. Soc. 118:339-342.

Lorenz, O. and D. Maynard (eds.). 1988. Knott's handbook for vegetable growers. 3rd ed. Wiley, New York.

Marschner, H. 1986. Mineral nutrition of higher plants. Academic, New York.

Masson, J., N. Tremblay, and A. Gosselin. 1991a. Nitrogen fertilization and HPS supplemental lighting influence vegetable transplant production. I. Transplant growth. J. Amer. Soc. Hort. Sci. 116:594-598. 
Masson, J., N. Tremblay and A. Gosselin. 1991b. Effects of nitrogen fertilization and HPS supplemental lighting on vegetable transplant production. II. Yield. J. Amer. Soc. Hort. Sci. 116:599-602.

Melton, R.R. and R.J. Dufault. 1991a. Nitrogen, phosphorus, and potassium fertility regimes affect tomato transplant growth. HortScience 26:141-142.

Melton, R.R. and R.J. Dufault. 1991b. Tomato seedling growth, earliness, yield, and quality follow- ing pretransplant nutritional conditioning and low temperatures. J. Amer. Soc. Hort. Sci. 116:421-425.

SAS Institute. 1989. SAS/STAT user's guide. vol. 2, ver. 6,4 th ed. SAS Inst., Cary, N.C.

Tracy, W.W. 1908. Tomato culture. Orange Judd Co., New York.

Vavrina, C.S. and W. Summerhill. 1992. Florida vegetable transplant survey, 1989-1990. HortTechnology 2:480-483.

Weston, L.A. and B.H. Zandstra. 1989. Trans- plant age and $\mathrm{N}$ and $\mathrm{P}$ nutrition effects on growth and yield of tomatoes. HortScience 24:88-90.

Widders, I.E. 1989. Pretransplant treatments of $\mathrm{N}$ and $P$ influence growth and elemental accumulation in tomato seedlings. J. Amer. Soc. Hort Sci. 114:416-420.

Yelle, S., R.C. Beeson, M.J. Trudel, and A. Gosselin 1989. Acclimation of two tomato species to high atmospheric $\mathrm{CO}_{2}$. 1. Sugar and starch concentrations. Plant Physiol. 90:1465-1472. 